\title{
Література:
}

1. Кобелянська О. I. Морфологічні, функціональні та звукосимволічні особливості ономатопеїчної лексики в японському поетичному тексті // Мова і куль-тура. К. : ВД Дмитра Бураго, 2016. Вип. 19. Т. IV (179). С. 334-344.

2. Кобелянська О. I. Ономатопеїчна система сучасної японської мови. К. : ВД Дмитра Бураго, 2017. 294 с.

3. Кобелянська О. І., Егава Х. Японсько-український словник ономатопеїчної лексики. К. : ВД Дмитра Бураго, 2016. 320 с.

DOI https://doi.org/10.30525/978-9934-588-90-7-56

\section{РИСИ ДІАЛЕКТУ ЯМАТО В ТЕКСТІ «ОФУДЕСАКІ»}

\author{
Мазур C. М. \\ кандидат філологічних наук, \\ дочент кафедри іноземних мов математичних факультетів \\ Київський національний університет імені Тараса Шевченка \\ м. Київ, Украӥна
}

Канонічний текст під назвою «Офудесакі» (яn.: おふでさき - «На кінчику пензля») був «записаний зі слів Бога-Отця» засновницею Тенрійської релігії (яn.: 天理教 «Тенрі-кьо» - «Релігія Небесної Істини») Накаямою Мікі в період з 1869 по 1882 р. Доволі швидко ця нова синкретична релігія, яка органічно об'єднала в собі окремі концептуальні засади синтоїзму, буддизму i християнства, активно поширилася спочатку в районі Кансая (преф. Вакаяма, Кіото, Мie, Нара, Осака, Шіга, Хього), а згодом і на всій території Японії [1, с. 63-68; 2, с. 12-20].

Текст «Офудесакі» - це своєрідна лірично-філософська поема релігійного змісту, що складається з 1711 віршів-танка, в яких описано історію зародження людства, божественні діяння Бога-Отця, хронологію становлення релігії Тенрі, тлумачаться її головні морально-етичні засади, правила поведінки віруючих тощо. Цей релігійний текст став своєрідним конгломератом різних мовленнєвих стилів, до якого була широко залучена просторічна і діалектна лексика. Завдяки цьому він яскраво віддзеркалює особливості японської мови другої половини XIX ст. в іiі кансайському варіанті, що дозволяє розглядати його як цінне джерело дослідження загальнонаціональної літературної та розмовної мов цієї історичної доби, а також як джерело акцентуаційних, фонетичних, 
морфологічних, лексичних та граматичних особливостей тогочасного кансайського діалекту в цілому і його периферійного різновиду діалекту Ямато (преф. Нара) зокрема.

У тексті «Офудесакі» знайшли своє віддзеркалення практично всі головні особливості кансайського діалекту:

- використання зв’язки や [《я»] і やった;

- усічення закінчень прикметників; випадіння приголосного $[\kappa] \mathrm{y}$ прислівниках на $[\kappa y]$;

- заміщення приголосного звука $[c]$ звуком $[x]$;

- заміна нормативної для розмовної мови заперечувальної зв'язки ない [най] дієслівним суфіксом へん $[x е н]$;

- скорочення подовжених голосних звуків наприкінці слів чи словоформ;

- використання специфічних форм слів, особливих формул мовленнєвого етикету тощо [докл. про це див.: 3].

Більш детальний лінгвістичний аналіз тексту «Oфудесакі» дозволяє виявити також окремі типові риси тогочасного діалекту Ямато (преф. Нара). Зокрема йдеться про такі мовні явища, як:

1. Регулярні фонемні зміни (яn.: 音韻変化 - «он-ін хенка»): $e-i, u-o$, mи-и, yan-an, shi-hi, ke-ki та ін.

2. Послідовне заміщення приголосних звуків ряду [«ca», «mi», «cy», «ce», «со»] рядом [«xa»,, «xi»,, «фуy», «xe», «xо»], а також ряду [«дза» ...] рядом $[« \partial a » \ldots]$.

\section{3. Подвоєння (подовження) голосних:}

a) [«коно йо»-このよ] - [《коно йоу» - このよふ $]$ яn.: この世 - цей світ;

[«pi»»-り] - [«piii»-りい] яn.: 理 - резон, доказ, причина;

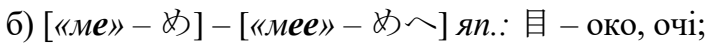

в) [«шіккарі»-しつかり]-[«шіїкарі»-しいかり]яn.: しっかり наполегливо, старанно, як слід, належним чином, з усіх сил.

4. Діалектне чергування голосних звуків в окремих словах:

[«ко»-こ, «сукояка-ні»] - [«кі»-き, «сукіяка-ні»] яп.: 健やかにжваво бадьоро, енергійно; ретельно, старанно.

5. У тексті «Офудесакі» простежується ще одна цікава закономірність, що характеризує граматичні особливості діалекту Ямато початку доби Мейджі (1868-1912) і пов'язана з уживанням певних дієслів. Так, у сучасній японській мові дієслова: «ісаму» (勇む підбадьорюватися, підноситися духом); «иукусу» (尽くす - вичерпувати, 206 
витрачати /всі сили/, віддаватися /повністю до кінця/); «юрусу» (許す— дозволяти, допускати; пробачати, прощати, відпускати /гріхи/); «ватасу» (渡す- передавати, підносити; переправляти) та інші відносяться до так званої «чотириступеневої» («п’ятиступеневої») дієвідміни, проте в тексті «Oфудесакi» вони зазвичай наводяться у формі «двоступеневої» дієвідміни «ісамуру», «цуку-суру», «юрусуру», «ватасуру», наприклад:

このもとをしりたるものかあるならば

たづねいてみよ神がゆるする (6-27)

Якщио існує той, хто знає першопричини всього сущуого,

Іоіть $і$ запитайте в нього! Бог дозволяє!

ぢきもつをたれにあたへる事ならば

このよはじめたをやにわたする (9-61)

Кому, на вашу думку, буде дарована Небесна страва?

Вона буде піднесена Богу - Творињю цьього світу.

Текст «Офудесакі» яскраво віддзеркалює також деякі морфологічні особливості лексики діалекту Ямато, специфічні форми словотвору, нестан-дартні граматичні конструкції тощо, наприклад:

1. 知らん [«шіран»-《не знати»], літературне нормативне: 知らな い[《шіранай»];

わからん [«вакаран»-«не розуміти»], літературне нормативне: 分か らない [《вакаранай»];

いらん[«іран»- «не потрібний»; «не слід», «не варто»], літературне нормативне: いらない [《іранай»];

きたらん[«кітаран» - «не прийти», «не наступити», «не настати»], літературне нормативне: 来たらない [«кітаранай»].

2. なんぼ [«намбо»-«скільки?»], літературне нормативне: いくら [«iкура»].

3. しやんせ(ん)よ, しやん(を)して [«иіянсе(н)йо», «иіян(-о)иіте»], літературне нормативне: かんがえなさい [《кангаенасай»] - поміркуйте! подумайте!

4. いかんで [«іканде»-«не можна ...», «не слід...»], літературні нормативні: 行けない [«ікенай»], 行けません [«ікемасен»] від дієслова 行ける [《ікеру»-《уміти ...», «могти ...», «мати можливість] .

5. みへんか [«міхен-ка» - «не бачите?», «не помічаєте?»], літературне нормативне: 見えないか [《міенай-ка»].

6. やない [《янай» /заперечувальна форма/ - «не ...», «неможливо ...»], літературні нормативні: ではない [«дева-най»], じゃない [«джя-най»] [докл. про иче див.: 4]. 
Слід зазначити також, що, усвідомлюючи значення сакрального тексту «Офудесакі» для віруючих, засновниця Тенрійської релігії Накаяма Мікі обрала для його написання поетичний жанр танка, який вимагав традиційного вико-ристання мови бунто (文語, досл.: «писемна мова»), в основу якої лягла вишукана японська мова аристократів столиці країни Кіото доби Хейан (VIII-XII ст.) 3 характерною для неї лексикою, граматикою, синтаксисом, художньо-стилістичними засобами, образністю тощо. 3 іншого боку, демократичні зміни в літературній мові, які відбувалися в тогочасному японському суспільстві, а також специфіка аудиторії, для якої призначався текст і яка не володіла достатньою мірою мовою бунто, диктували необхідність широкого залучення сучасної розмовної лексики, використання відповідних граматичних форм та синтаксичних конструкцій, характерних насамперед для звичної $\mathrm{i}$ зрозумілої потенційними реціпієнтами канонічного тексту «Офудесакі» мови кого (口語) - некодифікованої розмовної японської мови, в основі якої лежали численні місцеві діалекти та говірки, і яка, до речі, тривалий час вважалася вульгарною.

На нашу думку, зафіксовані в «Офудесакі» фонетичні особливості розмовної та діалектної лексики, як і деякі граматичні форми, не властиві японській літературній мові, підтверджують гіпотезу про те, що конвергентне зближення розмовного мовлення з літературною мовою мало двосторонній напрямок. Не лише мова художньої літератури передусім через систему освіти активно впливала на нормативну базу національної мови, а й розмовна стихія мала суттєвий вплив на тогочасну японську мову, значною мірою «розмиваючи» ii визначені літературною традицією межі, тобто змінюючи лексичний склад, граматичні правила, стилістичні норми тощо.

\section{Література:}

1. Светлов Г.Е. Новые религии Японии. Этнографическое обозрение. 1994, № 2. C. 58-70 [EP: https://buddha.by/novye-religii-yaponii].

2. Inoue A. A Study of the Ofudesaki: The original Scripture of Tenrikyo / A. Inoue, M. Eynon. Tenrikyo Doyusha, 1987. 515 p.

3. Мазур С.М. Розмовні елементи в лексиці канонічних текстів Тенрійської релігії (на матеріалі «Офудесакі») / Мовні і концептуальні картини світу. Збірник наукових праць. Випуск 45. К. : ВД Дмитра Бураго, 2013. С. 53-59.

4. Семенко (Мазур) С.М. «Офудесакі» як джерело японської мови XIX ст. (На-укова монографія). К. : ВД Дмитра Бураго, 2017. 381 с. 